\title{
PENINGKATAN PERILAKU HIDUP BERSIH DAN SEHAT (PHBS) PADA PENDIDIK DAN PESERTA DIDIK DI KECAMATAN LEIHITU BARAT KABUPATEN MALUKU TENGAH
}

\author{
Gracia V. Souisa ${ }^{1 *}$, Ivy V. Lawalata ${ }^{1}$, Samuel Titaley ${ }^{1}$, Bellytra Talarima ${ }^{1}$ \\ ${ }^{1}$ Fakultas Kesehatan, Universitas Kristen Indonesia Maluku, Ambon, Indonesia \\ *Penulis Korespendensi: souisagracia@gmail.com
}

\begin{abstract}
Abstrak
Program Kemitraan Masyarakat SD Negeri 1 dan 2 Hatu, dilakukan berdasarkan permasalahan dari mitra yaitu pengetahuan yang masih rendah berdampak pada kurangnya perilaku hidup bersih dan sehat dari siswa/i, tidak adanya program Perilaku Hidup Bersih dan Sehat (PHBS), serta tidak tersedianya fasilitas penunjang PHBS. Tujuan kegiatan ini adalah meningkatkan pengetahuan dan membudayakan PHBS di sekolah. Metode yang digunakan yaitu penyuluhan, pendampingan, praktek masal, dan pemeriksaan kecacingan. Kegiatan ini dilakukan pada bulan Mei - Juni 2018. Hasil yang didapatkan adalah (1). Kegiatan penyuluhan bagi peserta didik di SD Negeri 1 Hatu, pengetahuan meningkat yaitu untuk nilai baik $(\geq 70)$ dari 42 orang (87,5\% - pretest) menjadi 45 orang (93,7\% posttest), dan nilai median meningkat dari 80 menjadi 90; (2). Kegiatan penyuluhan di SD Negeri 2 Hatu, pengetahuan siswa meningkat yaitu untuk nilai baik $(\geq 70)$ dari 66 orang $(86,9 \%)$ menjadi 71 orang (93,5\%) dan nilai median meningkat dari 85 menjadi 90; (3). Kegiatan praktek meliputi cuci tangan, menggosok gigi dan memilah sampah; (4). Kegiatan Focus Discussion Group mendorong pimpinan sekolah dan guru untuk membudayakan PHBS; (5). Pemeriksaan kecacingan didapatkan 5 sampel positif Ascaris lumbricoides dari total 12 sampel. Kesimpulan, terjadi peningkatan pengetahuan peserta didik tentang PHBS, ada komitmen pimpinan sekolah untuk membudayakan PHBS.
\end{abstract}

Kata Kunci: Sekolah Dasar, Perilaku Hidup Bersih dan Sehat

\begin{abstract}
Community Partnership Program Public Elementary School 1 and 2 Hatu, conducted based on the problems of partners that is still low knowledge impact on the lack of clean and healthy life behavior (CHLB) of students, the absence of CHLB program, and the unavailability of CHLB support facilities. The purpose of this activity is to increase knowledge and civilize PHBS in schools. The method used is counseling, mentoring, mass practice, and examination of worms. This activity was conducted in May - June 2018. The results obtained are (1). The extension activities for students in Public Elementary School 1 Hatu, improved knowledge for good grades $\geq 70)$ from 42 people $(87,5 \%$ - pretest) to 45 people (93,7\% - posttest), and median value increased from 80 to 90; (2). The extension activities at Public Elementary School 2 Hatu, the students' knowledge increased for good value ( $\geq 70)$ from 66 people (86,9\%) to 71 people (93,5\%) and median value increased from 85 to 90; (3). Practical activities include hand washing, brushing and disposing of garbage; (4). The Focus Discussion Group activities encourage school leaders and teachers to cultivate CHLB; (5). There were 5 positive samples of Ascaris lumbricoides from a total of 12 samples. Conclusion, there is an increase of learners knowledge about $C H L B$, there is commitment of school leadership to civilize CHLB.
\end{abstract}

Keywords: Public Elemnetary School, Clean and Healthy Life Behavior

\section{PENDAHULUAN}

Perilaku Hidup Bersih dan Sehat (PHBS) di Sekolah adalah sekumpulan perilaku yang dipraktikkan oleh peserta didik, guru dan masyarakat lingkungan sekolah atas dasar kesadaran sebagai hasil pembelajaran, sehingga secara mandiri mampu mencegah penyakit, meningkatkan kesehatannya, serta berperan aktif dalam mewujudkan lingkungan sehat (Sulastri, Purna, \& Suyasa, 2014). Beberapa indikator PHBS di sekolah antara lain mencuci tangan dengan air yang mengalir dan memakai sabun, mengkonsumsi jajanan sehat di kantin sekolah, menggunakan jamban yang bersih dan sehat, olahraga yang teratur dan terukur, memberantas jentik nyamuk, tidak merokok di sekolah, menimbang berat badan dan mengukur tinggi badan setiap bulan, dan membuang sampah pada tempatnya. Dalam UU No 36 tahun 2009 pasal 79 tentang Kesehatan, ditegaskan bahwa 
"Kesehatan Sekolah diselenggarakan untuk meningkatkan kemampuan hidup sehat peserta didik dalam lingkungan hidup sehat sehingga peserta didik dapat belajar, tumbuh dan berkembang secara harmonis dan setinggi - tingginya sehingga diharapkan dapat menjadi sumber daya manusia yang berkualitas (Kementerian Kesehatan RI, 2011).

Perilaku hidup bersih dan sehat mempengaruhi status kesehatan individu, sehingga penting untuk diterapkan dalam kehidupan setiap hari. Pengetahuan merupakan salah satu faktor pembentuk perilaku. Tinggi rendahnya pengetahuan dapat dipengaruhi oleh proses belajar dan lingkungan. Pengetahuan akan konsep hidup bersih dan sehat berdampak pada perilaku individu dan mempengaruhi status kesehatan individu. Anak - anak merupakan generasi penerus bangsa yang penting untuk diperhatikan kesehatannya. Anak - anak juga termasuk dalam kelompok yang rentan dengan berbagai gangguan kesehatan dan sangat bergantung kepada orang tua. Sekalipun demikian, anak - anak sangat potensial untuk dipengaruhi dan diberi motivasi sehingga membiasakan sejak dini perilaku hidup bersih dan sehat. Perilaku orang dewasa tidak mudah untuk diubah, namun perilaku anak sangat mungkin untuk diubah dengan memberikan pengetahuan dan contoh. Penelitian yang dilakukan Banun (2016), menunjukan ada hubungan positif antara pengetahuan PHBS dengan pola hidup sehat siswa di SD Tamanan. Penelitian lainnya yang dilakukan Koem et al. (2015), menunjukan ada hubungan antara tingkat pengetahuan dan sikap siswa dengan penerapan PHBS di SD INPRES Sukur, Minahasa Utara. Sedangkan faktor lain yang berhubungan dengan penerapan PHBS dalam penelitian Sari et al. (2016) di SD N Karangtowo, Kabupaten Demak adalah dukungan lingkungan sekolah dan sarana prasarana.

Sekolah Dasar Negeri 1 dan Negeri 2 Desa Hatu, merupakan mitra Program Kemitraan Masyarakat (PKM) yang dipilih oleh tim pelaksana berdasarkan hasil diskusi dan observasi langsung dengan mitra. Jumlah siswa adalah 176 anak pada SD Negeri 1 dan 157 anak pada SD Negeri 2. Hasil observasi menunjukan beberapa masalah terkait PHBS antara lain tidak adanya tempat sampah di depan kelas, pengolahan sampah dengan membakar sampah menjadi satu - satunya alternatif pengolahan sampah, tidak tersedia sabun dan air mengalir untuk mencuci tangan, kantin sehat belum terselenggara karena keterbatasan sumber daya, tidak aktifnya Usaha Kesehatan Siswa (UKS) karena tidak tersedianya ruangan khusus (keterbatasan ruangan), sehingga berbagai program UKS seperti perilaku hidup bersih dan sehat belum dilaksanakan.

Selain pengetahuan peserta didik, peran pimpinan sekolah dan guru juga dibutuhkan untuk membudayakan PHBS di sekolah. Penelitian Diana et al. (2014), menyatakan bahwa terdapat hubungan yang bermakna antara pengetahuan dan peran guru dengan pelaksanaan program PHBS, sehingga diperlukan pelatihan, penyuluhan dan memperbanyak media promosi. Keberadaan UKS sangat penting untuk memperkenalkan dunia kesehatan dan membudayakan perilaku hidup bersih dan sehat sejak dini kepada peserta didik (Bina Kesehatan Anak, 2015). Pengenalan kesehatan kepada peserta didik diupayakan oleh SD Negeri 1 dan 2 Hatu hanya melalui guru olahraga.

Data yang diambil dari posyandu setempat menunjukan adanya penyakit seperti infeksi saluran pernafasan atas (ISPA), infeksi kulit, anemia, diare, dermatitis yang merupakan kelompok penyakit yang berhubungan dengan perilaku hidup bersih dan sehat. Hasil observasi dan diskusi tentang perilaku anak di sekolah menunjukan masih rendahnya kesadaran anak tentang PHBS sehingga perlu penyuluhan, praktek massal dan pendampingan guru dengan harapan memotivasi anak untuk membiasakan perilaku hidup bersih dan sehat sejak dini. Diskusi dengan Kepala Sekolah SD Negeri 1 tentang penyakit yang biasa dialami oleh anak sehingga tidak ke sekolah adalah batuk dan demam, sedangkan pada SD Negeri 2, diskusi yang dibangun dengan salah satu guru menyatakan bahwa penyakit yang biasa dialami oleh anak adalah sakit perut akibat tidak sarapan. Hasil penelitian Noverawati et al. (2012), menunjukan bahwa sebagian besar siswa SDN Hegarmanah tidak mencuci tangan dengan air mengalir dan memalai sabun sebelum dan sesudah jajan, karena malas dan kebiasaan, sehingga gampang terserang penyakit seperti diare, kecacingan dan gangguan pencernaan.

Salah satu indikator untuk memonitor kurangnya perilaku hidup bersih dan sehat adalah mikroskopik kecacingan pada anak. Kecacingan merupakan salah satu penyakit yang berbasis lingkungan sehingga perhatian terhadap sanitasi lingkungan perlu ditingkatkan. Kecacingan menunjukan kurangnya PHBS seperti kesadaran mencuci tangan sebelum makan, sesudah buang air besar, tidak menggunakan alas kaki ketika bermain di luar rumah, dan kebersihan kuku. Kecacingan dapat menyebabkan menurunnya kondisi kesehatan, gizi, kecerdasan dan produktivitas, kecacingan pada anak menimbulkan kekurangan gizi yang menetap, dikemudian hari akan menimbulkan dampak pendek menurut umur (Stunting), kurangnya penyerapan nutrisi, anemia, hingga gangguan pertumbuhan pada anak, sehingga penting untuk monitoring kecacingan pada anak (Rahmadhini \& Mutiara, 2015). Bertolak dari situasi diatas, maka dilaksanakanlah Program Kemitraan Masyarakat (PKM) kepada mitra untuk menerapkan perilaku hidup bersih dan sehat, yaitu melalui kegiatan penyuluhan, pendampingan, praktek masal, dan mikroskopik kecacingan.

\section{BAHAN DAN METODE}

Metode yang digunakan dalam pemecahan permasalahan antara lain penyuluhan, pendampingan, praktek masal dan pemeriksaan kecacingan. Penyuluhan dengan metode ceramah dan media leaflet 
untuk meningkatkan pengetahuan peserta didik tentang PHBS tatanan sekolah yang dikur melalui pretest dan posttest dengan kategori nilai $<70$ untuk kategori cukup dan $\geq 70$ untuk kategori baik. Selain penyuluhan, juga dilakukan pendampingan (focus discussion group) bagi para guru untuk mendorong pembudayaan PHBS di sekolah melalui rencana kerja sekolah atau program UKS. Praktek masal dilakukan untuk menjadi contoh aktivitas sehingga terjadi pembudayaan PHBS dan pemeriksaan kecacingan untuk memonitor adanya indikasi kurangnya penerapan PHBS. Data yang didapatkan dianalisis secara deskriptif untuk menggambarkan adanya peningkatan pengetahuan siswa dan pembudayaan PHBS di sekolah.

\section{HASIL DAN PEMBAHASAN}

Kegiatan penyuluhan bertujuan untuk meningkatkan pengetahuan dan pemahaman tentang perilaku hidup bersih dan sehat (PHBS) khususnya pada tatanan sekolah, sehingga peserta didik dapat membiasakan hidup bersih dan sehat sejak dini. Kegiatan penyuluhan melibatkan 3 orang dosen dan 4 orang mahasiswa Fakultas Kesehatan Universitas Kristen Indonesia Maluku (UKIM). Kegiatan berlangsung pada 28 Mei 2018, untuk peserta didik kelas I - VI di SD Negeri 1 dan SD Negeri 2 Hatu. Untuk memudahkan pemahaman peserta didik, tim menggunakan leaflet/ brosur yang berisi materi tentang PHBS tatanan sekolah. Selain itu juga digunakan lembar pretest dan posttest yang berisi 10 pertanyaan tentang PHBS tatanan sekolah, yang dijawab oleh peserta didik dengan menyilang pada pilihan benar (B) atau salah (S).

Tim berangkat pada pukul 08.00 WIT dengan menggunakan 2 unit mobil yang juga mengangkut perlengkapan PKM seperti tempat sampah, penampungan air, sikat gigi, pasta gigi, sabun cair dan perlengkapan lainnya. Sebelum berangkat, dilakukan pertemuan singkat dengan tim, untuk membicarakan pembagian tugas dan teknik pelaksanaan penyuluhan. Kegiatan dimulai pada pukul 09.30 WIT di SD Negeri $1 \mathrm{Hatu}$, siswa dibagi atas 2 kelas yaitu gabungan kelas I, II, gabungan kelas III - VI dengan total jumlah siswa yang hadir adalah 92 orang. Penyuluhan diawali dengan pembagian lembar pretest untuk mengukur tingkat pengetahuan peserta didik. Selanjutnya pembagian leaflet/ brosur dan penyampaian materi dilakukan oleh Tim (dosen) dan dibantu oleh mahasiswa dan guru. Setelah penyampaian materi, dilakukan evaluasi dengan menggunakan lembar posttest untuk melihat ada tidaknya peningkatan pengetahuan peserta didik. Peserta didik mengumpulkan lembar posttest dan menandatangani daftar hadir.

Pada kegiatan penyuluhan, juga dibagikan kotak sampel feces, untuk pemeriksaan kecacingan. Peserta didik sesuai dengan kelasnya diberi kotak sampel yang telah dibeli label sesuai inisial dan kelas. Kotak sampel hanya dibagikan pada peserta didik di kelas III - VI, dengan harapan peserta didik memahami proses pengambilan sampel feses dan dapat dikumpulkan pada hari Rabu, 30 Mei 2018. Jumlah kotak sampel yang dibagikan adalah 50\% dari jumlah siswa per kelas yang hadir saat penyuluhan. Setelah peserta didik yang mendapat kotak sampel diberi penjelasan, dibagikan snack.

Setelah penyuluhan selesai dilakukan di SD Negeri 1 Hatu, tim melanjutkan penyuluhan di SD Negeri 2 Hatu pada pukul 11.30 WIT, dengan total jumlah siswa yang hadir adalah 76 orang. Teknik pelaksanaan sama dengan yang dilakukan pada SD Negeri 1 Hatu, yaitu pembagian lembar pretest, pembagian leaflet, penyampaian materi, pengisian posttest, mengisi daftar hadir, pembagian kotak sampel dan pembagian snack. Hasil pretest dan posttest SD Negeri 1 dan SD Negeri 2 Hatu untuk menilai adanya peningkatan pengetahuan peserta didik, dapat dilihat pada tabel berikut :

Tabel 1. Hasil Pretest dan Postest Peserta Didik SD Negeri 1 Hatu

\begin{tabular}{|c|c|c|c|c|c|c|c|c|c|}
\hline \multirow{2}{*}{ Kelas } & \multirow{2}{*}{ Kategori Nilai } & \multicolumn{4}{|c|}{ Pretest } & \multicolumn{4}{|c|}{ Posttest } \\
\hline & & $\mathbf{n}$ & $\%$ & Mean & Median & $\mathbf{n}$ & $\%$ & Mean & Median \\
\hline \multirow[b]{2}{*}{ I } & Cukup $(<70)$ & - & - & & & 3 & 10,7 & \multirow{2}{*}{86,4} & \multirow{2}{*}{90} \\
\hline & Baik $(\geq 70)$ & - & - & & & 25 & 89,3 & & \\
\hline \multirow{2}{*}{ II } & Cukup $(<70)$ & - & - & \multirow[b]{2}{*}{-} & \multirow[b]{2}{*}{ - } & 1 & 6,3 & \multirow{2}{*}{89,3} & \multirow{2}{*}{90} \\
\hline & Baik $(\geq 70)$ & - & - & & & 15 & 93,7 & & \\
\hline \multirow{2}{*}{ III } & Cukup $(<70)$ & 4 & 22,2 & \multirow{2}{*}{76,6} & \multirow{2}{*}{75} & 0 & 0 & \multirow{2}{*}{83,8} & \multirow{2}{*}{80} \\
\hline & Baik $(\geq 70)$ & 14 & 77,7 & & & 18 & 100 & & \\
\hline \multirow{2}{*}{ IV } & Cukup $(<70)$ & 1 & 6,2 & \multirow{2}{*}{81,8} & \multirow{2}{*}{80} & 2 & 12,5 & \multirow{2}{*}{88,7} & \multirow{2}{*}{90} \\
\hline & Baik $(\geq 70)$ & 15 & 93,7 & & & 14 & 87,5 & & \\
\hline \multirow{2}{*}{$\mathrm{V}$} & Cukup $(<70)$ & 1 & 7,1 & \multirow{2}{*}{80,7} & \multirow{2}{*}{80} & 1 & 7,1 & \multirow{2}{*}{89,2} & \multirow{2}{*}{90} \\
\hline & Baik $(\geq 70)$ & 13 & 92,9 & & & 13 & 92,9 & & \\
\hline \multirow{2}{*}{ VI } & Cukup $(<70)$ & - & - & & & - & - & \multirow{2}{*}{ - } & \multirow{2}{*}{-} \\
\hline & Baik $(\geq 70)$ & - & - & & & - & - & & \\
\hline \multirow{2}{*}{$\begin{array}{l}\text { TOTAL } \\
(\text { III }- \text { V) }\end{array}$} & Cukup $(<70)$ & 6 & 12,5 & \multirow[t]{2}{*}{79,5} & 80 & 3 & 6,3 & 87 & 90 \\
\hline & Baik $(\geq 70)$ & 42 & 87,5 & & & 45 & 93,7 & & \\
\hline
\end{tabular}


Tabel 1. menunjukan jumlah siswa dengan kategori nilai baik $(\geq 70)$ meningkat pada posttest dibandingkan pretest, persentase peningkatan tertinggi pada kelas III yaitu dari 77,7 \% pada pretest meningkat menjadi $100 \%$ pada posttest. Selain itu, nilai mean dan median pada posttest pun menunjukan adanya peningkatan dibandingkan dengan pretest. Hal ini menunjukan bahwa terjadi peningkatan pengetahuan pada peserta didik setelah diberikan penyuluhan dengan menggunakan metode ceramah dan media leaflet. Ada sel yang kosong pada kelas I dan II untuk pretest, karena siswa kesulitan dalam membaca. Pada posttest untuk kelas I dan II disiasati dengan membaca soal oleh tim dan dilanjutkan dengan pengisian jawaban oleh peserta didik kelas I dan II. Siswa kelas VI tidak ada yang hadir pada saat penyuluhan dilakukan. Grafik pretest dan posttest SD Negeri 1 Hatu (kelas III - V) dapat dilihat pada gambar berikut:

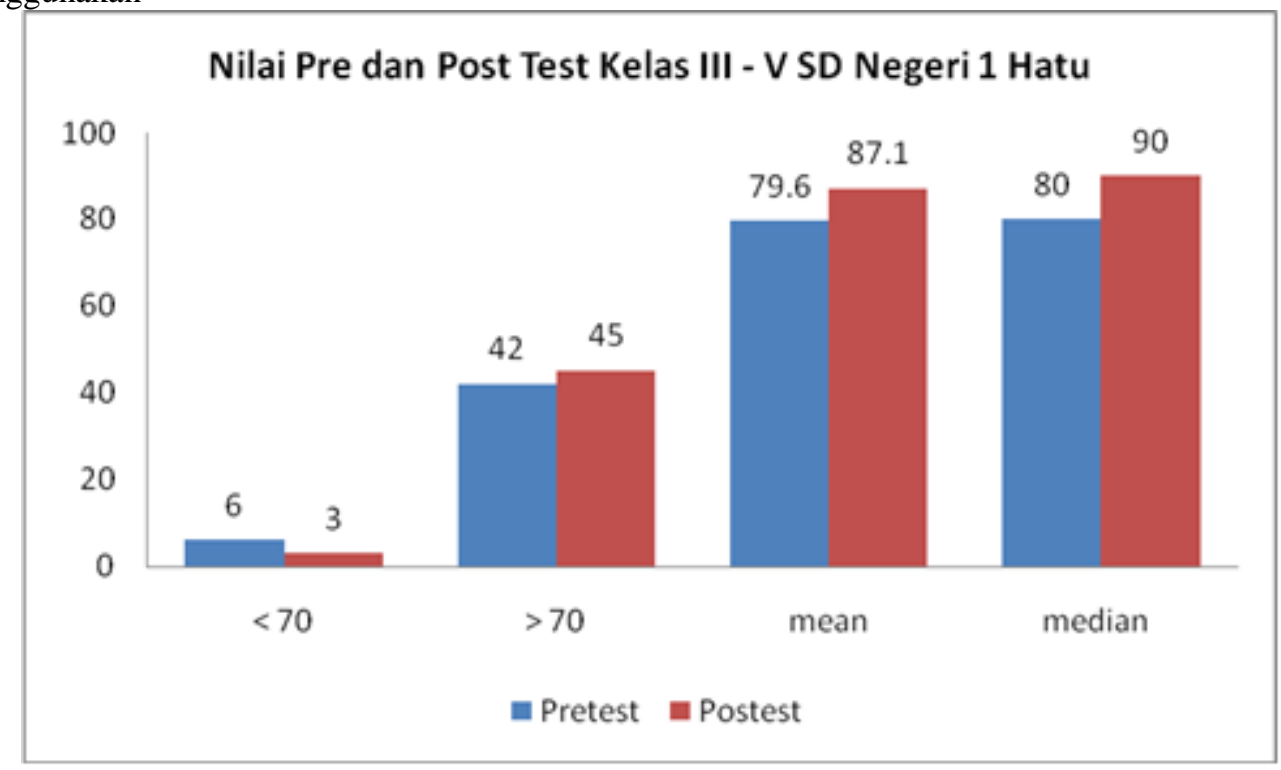

Gambar 1. Nilai Pre dan Post Test SD Negeri 1 Hatu

Gambar 1. menunjukan bahwa setelah dilakukan penyuluhan, pengetahuan siswa semakin meningkat yaitu untuk nilai baik $(\geq 70)$ dari 42 orang $(87,5 \%$ - pretest) menjadi 45 orang $(93,7 \%$
- posttest). Sedangkan nilai mean meningkat dari 79,6 menjadi 87,1 dan median meningkat dari 80 menjadi 90 .

Tabel 2. Hasil Pretest dan Posttest Peserta Didik SD Negeri 2 Hatu

\begin{tabular}{|c|c|c|c|c|c|c|c|c|c|}
\hline \multirow{2}{*}{ Kelas } & \multirow{2}{*}{ Kategori Nilai } & \multicolumn{4}{|c|}{ Pretest } & \multicolumn{4}{|c|}{ Posttest } \\
\hline & & $\mathbf{n}$ & $\%$ & Mean & Median & $\mathbf{n}$ & $\%$ & Mean & Median \\
\hline \multirow{2}{*}{ I } & Cukup $(<70)$ & 4 & 28,5 & \multirow{2}{*}{77,9} & \multirow{2}{*}{80} & 3 & 21,4 & \multirow{2}{*}{79,2} & \multirow{2}{*}{80} \\
\hline & Baik $(\geq 70)$ & 10 & 71,5 & & & 11 & 78,5 & & \\
\hline \multirow{2}{*}{ II } & Cukup $(<70)$ & 2 & 12,5 & \multirow{2}{*}{87,5} & \multirow{2}{*}{100} & 0 & 0 & \multirow{2}{*}{90} & \multirow{2}{*}{100} \\
\hline & Baik $(\geq 70)$ & 14 & 87,5 & & & 16 & 100 & & \\
\hline \multirow{2}{*}{ III } & Cukup $(<70)$ & 3 & 30 & \multirow{2}{*}{71} & \multirow{2}{*}{70} & 0 & 0 & \multirow{2}{*}{81} & \multirow{2}{*}{80} \\
\hline & Baik $(\geq 70)$ & 7 & 70 & & & 10 & 100 & & \\
\hline \multirow{2}{*}{ IV } & Cukup $(<70)$ & 0 & 0 & \multirow{2}{*}{90} & \multirow{2}{*}{90} & 0 & 0 & \multirow{2}{*}{90} & \multirow{2}{*}{100} \\
\hline & Baik $(\geq 70)$ & 9 & 100 & & & 9 & 100 & & \\
\hline \multirow{2}{*}{ V } & Cukup $(<70)$ & 0 & 0 & \multirow{2}{*}{87,1} & \multirow{2}{*}{90} & 0 & 0 & \multirow{2}{*}{90,6} & \multirow{2}{*}{100} \\
\hline & Baik $(\geq 70)$ & 17 & 100 & & & 17 & 100 & & \\
\hline \multirow{2}{*}{ VI } & Cukup $(<70)$ & 3 & 30 & \multirow{2}{*}{82} & \multirow{2}{*}{90} & 0 & 0 & \multirow{2}{*}{98} & \multirow{2}{*}{100} \\
\hline & Baik $(\geq 70)$ & 7 & 70 & & & 10 & 100 & & \\
\hline \multirow{2}{*}{ TOTAL } & Cukup $(<70)$ & 10 & 13,1 & \multirow[t]{2}{*}{83,5} & 85 & 5 & 6,5 & 87,5 & 90 \\
\hline & Baik $(\geq 70)$ & 66 & 86,9 & & & 71 & 93,5 & & \\
\hline
\end{tabular}

Tabel 2. menunjukan bahwa ada peningkatan nilai siswa dengan kategori nilai baik $(\geq 70)$ pada posttest dibandingkan pretest, persentase peningkatan tertinggi pada kelas II yaitu dari 87,5\% pada pretest meningkat menjadi $100 \%$ pada posttest. Selain itu, nilai mean dan median pada posttest pun menunjukan adanya peningkatan dibandingkan dengan pretest. Hal ini menunjukan bahwa terjadi peningkatan pengetahuan pada peserta didik setelah diberikan penyuluhan dengan menggunakan metode ceramah dan media leaflet. Grafik nilai pretest dan posttest SD Negeri 2 Hatu (Kelas I - VI), dapat dilihat sebagai berikut: 


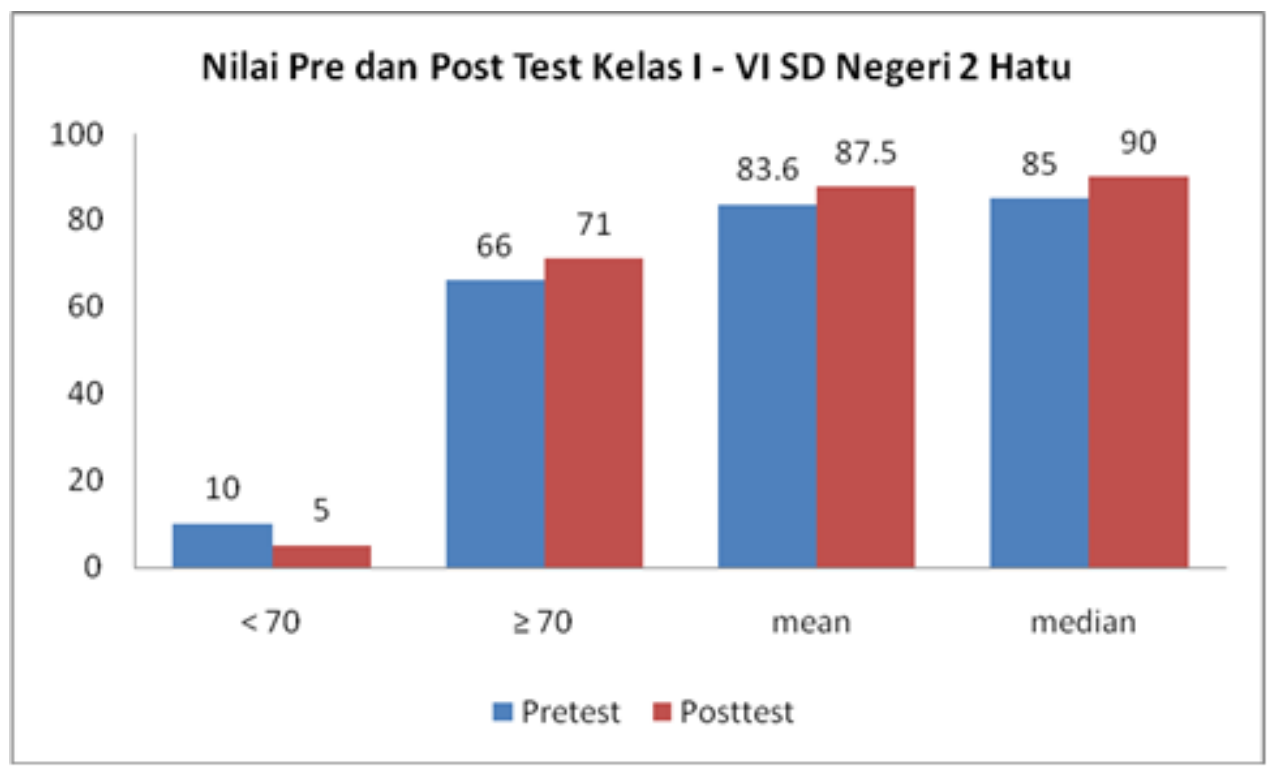

Gambar 2. Nilai Pre dan Post Test SD Negeri 2 Hatu

Grafik 5.2 menunjukan bahwa setelah dilakukan penyuluhan, pengetahuan siswa semakin meningkat yaitu untuk nilai baik $(\geq 70)$ dari 66 orang $(86,9 \%$ pretest) menjadi 71 orang $(93,5 \%$ - posttest $)$. Sedangkan nilai mean meningkat dari 83,6 menjadi 87,5 dan median meningkat dari 85 menjadi 90 . Pengetahuan akan konsep hidup bersih dan sehat berdampak pada perilaku individu dan mempengaruhi status kesehatan individu. Penelitian yang dilakukan Banun (2016), menunjukan ada hubungan positif antara pengetahuan PHBS dengan pola hidup sehat siswa di SD Tamanan. Penelitian lainnya yang dilakukan Koem et al. (2015), menunjukan ada hubungan antara pengetahuan, dukungan lingkungan sekolah dan sarana prasarana dengan perilaku hidup bersih dan sehat pada siswa SD N Karangtowo.

Selain penyuluhan, juga dilakukan praktek massal dengan tujuan memperkuat pemahaman dan melatih peserta didik untuk langsung mempraktekan perilaku hidup bersih dan sehat (PHBS). Beberapa perilaku yang dipraktekan antara lain cuci tangan pakai sabun (7 langkah mencuci tangan), membuang sampah sesuai jenisnya (organic dan anorganik) dan menggosok gigi yang benar. Praktek massal penting dilakukan sehingga peserta didik dapat mengingat materi yang diberikan dengan lebih baik. Kegiatan praktek massal memerlukan alat dan bahan yang telah

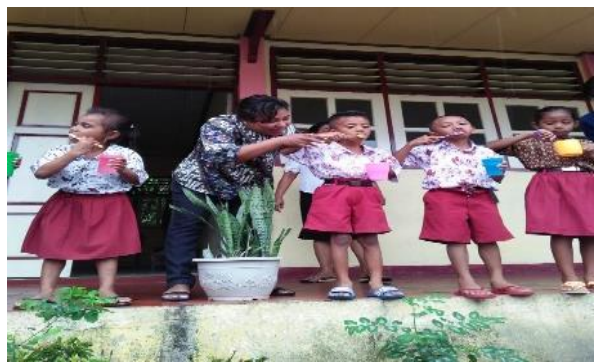

disediakan oleh tim antara lain sikat gigi, pasta gigi, penampungan air, sabun cuci tangan, tempat sampah yang diberikan kepada masing - masing sekolah.

Praktek massal dilakukan pada hari yang berbeda pada masing - masing sekolah, yaitu tanggal Rabu, $30 \mathrm{Mei}$ 2018 di SD Negeri 1 Hatu dan Kamis, 31 Mei 2018 di SD Negeri 2 Hatu. Praktek massal diawali dengan mempersiapkan perlengkapan praktek seperti air dalam gallon penampung air, sikat gigi, pasta gigi, sabun dan tempat sampah. Dalam kegiatan praktek massal, peserta didik lebih dulu memulai praktek 7 langkah mencuci tangan pakai sabun. Untuk memudahkan, peserta didik diajari dalam bentuk lagu dan praktek secara bergilir. Selanjutnya peserta didik dibagikan sikat dan pasta gigi, dan mempraktekan cara menggosok gigi yang benar. Peserta didik sangat antusias dalam mengikuti kegiatan praktek massal. Praktek yang terakhir adalah memilah sampah sesuai jenisnya. Pada praktek ini, beberapa orang siswa diberi beberapa jenis sampah seperti plastik, sisa kue, kaleng dan diarahkan untuk membuang pada tempat sampah yang sesuai, berlabel sampah organic dan anorganik. Untuk mengefisienkan pelaksanaan praktek massal, tim melibatkan 3 - 4 orang mahasiswa dan guru pendamping dari masing - masing sekolah. Setelah praktek massal selesai dilakukan, peserta didik diberi snack dan melanjutkan aktifitas lainnya.

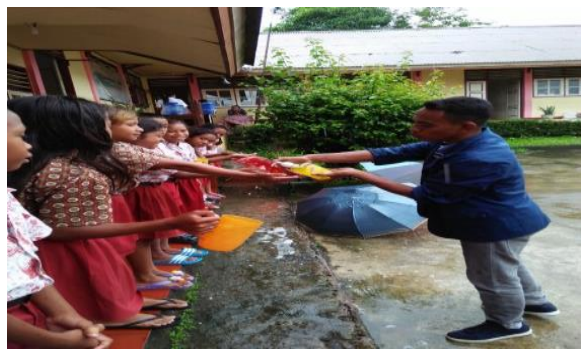

Gambar 3. Kegiatan Praktek Masal 
Kegiatan lainnya yang disepakati dan dilaksanakan dalam program, kemitraan masyarakat adalah focus discussion group (FGD) yang bertujuan untuk memberi pendampingan bagi para pendidik sehingga penerapan PHBS dapat terus berlangsung/ berkelanjutan. Luaran yang diharapkan dari FGD adalah dihasilkannya program kerja dan pedoman penyelenggaraan/ penerapan PHBS di sekolah. Kegiatan FGD SD Negeri 1 dan 2 Hatu, berlangsung pada Rabu 30 Mei 2018, pukul 11.00, tempat pelaksanaan di SD Negeri 1 Hatu dan dihadiri oleh 15 orang guru dari SD Negeri 1 Hatu dan 5 guru dari SD

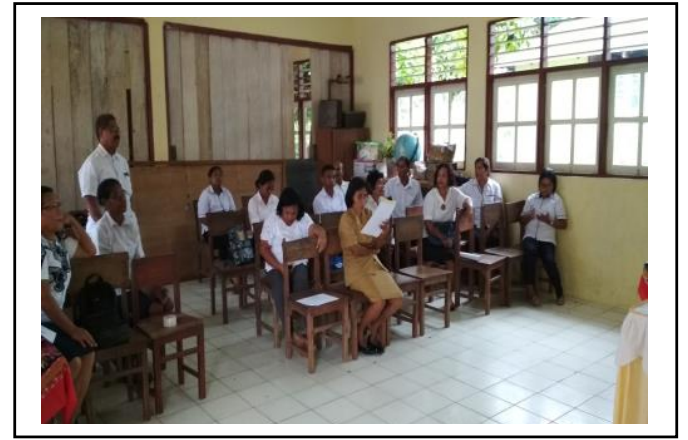

Negeri 2 Hatu. Tahapan pelaksanaan kegiatan ini antara lain :

a. Pembukaan ( Oleh Kepala Sekolah SD Negeri 2 Hatu)

b. Acara Inti (Penyampaian materi tentang gambaran umum penerapan PHBS di Sekolah dan Diskusi)

c. Penutup (Serah terima perlengkapan/ sarana penunjang PHBS)

Untuk memberikan gambaran tentang pelaksanaan PHBS di sekolah, tim menyiapkan draft pedoman pelaksanaan yang diberikan kepada guru dan dilengkapi/ ditambahkan kembali oleh tim, berdasarkan hasil FGD.

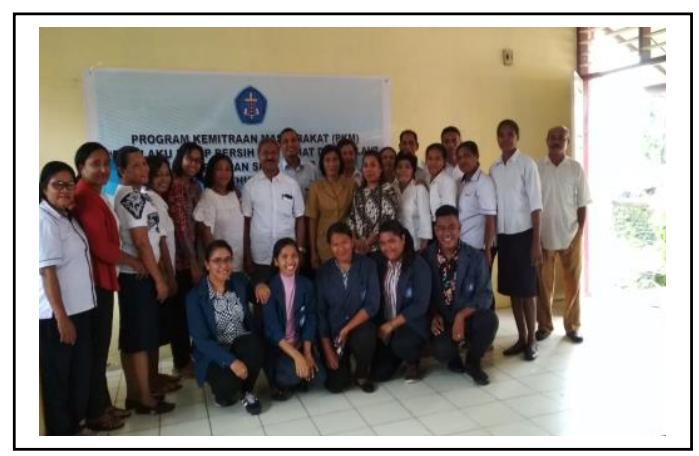

Gambar 4. Kegiatan Focus Discussion Group

FGD berjalan dengan baik, dan guru menyampaikan kendala - kendala yang dihadapi dalam pelaksanaan PHBS di sekolah. Pemateri yang menyampaikan gambaran umum pelaksanaan PHBS di sekolah, berpengalaman sebagai tim bahkan penilai Sekolah Dasar Bersih Sehat, Dinas Pendidikan dan Kebudayaan Provinsi Maluku, yang juga adalah Ketua Program Studi Kesehatan Masyarakat, Fakultas Kesehatan, UKIM. Diskusi berlangsung menarik karena ada berbagai sharing tentang kendala yang dihadapi seperti sarana/ fasilitas yang tidak dijaga dengan baik, tidak adanya ruang UKS, pelaksanaan PHBS yang tidak rutin, belum adanya kebijakan pimpinan sekolah untuk rutin melaksanakan PHBS, masih adanya guru yang merokok di sekolah, luas sekolah dan dana yang terbatas, serta kendala lainnya. Hasil diskusi menyimpulkan bahwa pentingnya pembudayaan PHBS di sekolah sejak dini dan berkelanjutan, memberi himbauan sehingga fasilitas penunjang PHBS dapat terjaga dengan baik, dapat dimulai dengan menerapkan sekolah bebas dari asap rokok, pentingnya sosialisasi ke orang tua sehingga mendapat dukungan agar ritme penerapan PHBS dapat terjaga hingga di rumah, penerapan PHBS dilakukan bertahap. Diskusi menjadi semakin menarik, karena ada komitmen dari Kepala Sekolah untuk menjalankan PHBS secara bertahap dan membudayakan PHBS kepada peserta didik melalui aksi - aksi sederhana yang terus berlanjut, kerjasama dengan komite sekolah, dan diprogramkan pada rencana kerja sekolah (RKS). Setelah selesai kegiatan FGD, dilanjutkan dengan penyerahan beberapa sarana penunjang pelaksanaan PHBS kepada masing masing sekolah yang diwakili oleh kepala sekolah. Beberapa perlengkapan yang diberikan antara lain tempat sampah, sikat gigi, pasta gigi, penampung air, sabun cuci tangan, poster 7 langkah cuci tangan dan poster kawasan bebas asap rokok.

Pemeriksaan kecacingan juga dilakukan dalam rangkaian kegiatan PKM untuk mengetahui ada tidaknya infeksi kecacingan pada peserta didik akibat kurangnya perilaku hidup bersih dan sehat (PHBS). Cacingan adalah penyakit yang disebabkan oleh infeksi cacing dalam tubuh manusia yang ditularkan melalui tanah. Pemeriksaan kecacingan di SD Negeri 1 dan 2 Hatu, dilakukan pada hari Rabu, 30 Mei 2018, disela - sela pelaksanaan praktek massal bagi SD Negeri 1 dan FGD bagi guru SD Negeri 1 dan 2 Hatu. Tahapan pemeriksaan antara lain pengumpulan kotak sampel feces pada SD Negeri 1 dan 2 Hatu, persiapan alat dan bahan, perlakuan sampel, pemeriksaan mikroskopik, dan pencatatan hasil. Pemeriksaan kecacingan dilakukan pada pukul 09.00 WIT oleh analis kesehatan dengan beberapa langkah perlakuan sampel antara lain pembuatan apusan feses pada kaca slide dengan menggunakan tusuk gigi, selanjutnya diwarnai dengan eosin, tutup dengan deg glass, amati adanya telur cacing dan identifikasi jenisnya berdasarkan morfologi dengan pembesaran 10x atau 40x pada mikroskop. Hanya ada 12 sampel feces yang dibawa oleh peserta didik, karena kurangnya pemahaman peserta didik tentang pemeriksaan kecacingan dan tidak nyaman bagi peserta didik untuk membawa feses ke sekolah sekalipun didalam kotak sampel. Hasil pemeriksaan menunjukan bahwa dari 12 sampel feses, ada 5 sampel yang positif telur cacing Ascaris lumbricoides. 

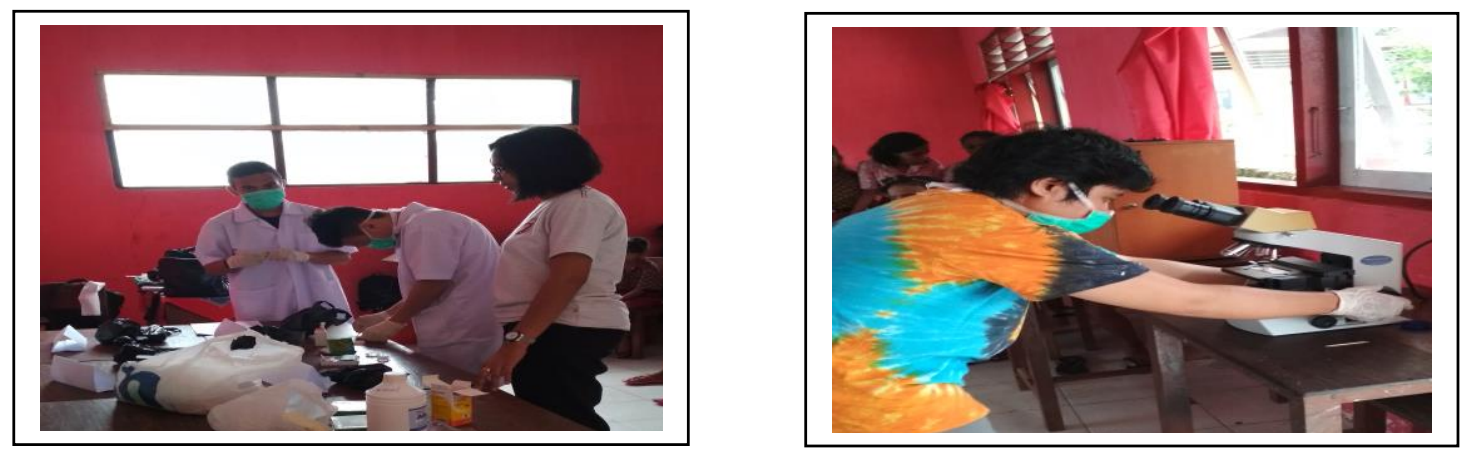

Gambar 5. Pemeriksaan Kecacingan

Hasil observasi menunjukan bahwa peserta didik ketika bermain diluar rumah tidak menggunakan alas kaki, ditambah dengan lingkungan Desa Hatu yang banyak memiliki peliharaan anjing yang membuang kotoran sembarangan, kebersihan kuku tidak diperhatikan dengan baik, serta kurangnya kesadaran mencuci tangan pakai sabun. Pada anak infeksi kronis cacing gelang dapat menyebabkan kegagalan pertumbuhan akibat penurunan nafsu makan, terganggunya proses pencernaan dan malabsorbsi.

Kecacingan banyak ditemukan di daerah dengan kelembaban tinggi terutama pada kelompok masyarakat dengan kebersihan diri dan sanitasi lingkungan yang kurang baik. Salah satu penyakit kecacingan adalah penyakit cacing usus yang ditularkan melalui tanah atau soil transmitted helmints. Jenis cacing yang terpenting adalah cacing gelang (Ascaris lumbricoides), cacing tambang (Ancylostoma duodenale), Necator americanus, dan cacing cambuk (Trichuris trichiura). Faktor - faktor risiko yang yang berpengaruh terhadap terjadinya infeksi cacing tambang adalah factor karakteristik (umur, jenis kelamin, imunitas), factor lingkungan fisik (tekstur tanah, kelembaban tanah, adanya lahan pertanian/ kebun, kondisi sanitasi sekolah dan rumah), factor biologis (keberadaan cacing tambang pada kotoran anjing atau kucing atau tanah), factor sosial ekonomi (pekerjaan, pendidikan, penghasilan), factor budaya (pelihara anjing, kucing, bermain tanpa alas kaki, defekasi sembarang tempat), dan factor lain yaitu ada tidaknya program pemberantasan penyakit kecacingan pada anak sekolah (Bisara \& Mardiana, 2014). Penelitian yang dilakukan Chadijah et al. (2014) di Sekolah Dasar Kota Palu menunjukan bahwadari 288 siswa SD, 90 sampel positif teridentifikasi cacing, dan jenis cacing yang paling dominan adalah Ascaris lumbricoides (83,34\%). Penelitian Nuryani \& Yustitia (2017) menunjukan ada hubungan cuci tangan, kebersihan kuku tangan dan penggunaan alas kaki dengan penyakit kecacingan pada anak sekolah dasar di Dusun Pangkul, Lampung Utara.

Untuk memelihara kesehatan dan mencegah kecacingan, dapat dilakukan upaya promosi kesehatan untuk meningkatkan perilaku hidup bersih dan sehat melalui program usaha kesehatan sekolah, media cetak maupun elektronik, penyuluhan langsung, bimbingan dan konseling, intervensi perubahan perilaku, dan pelatihan. Perilaku hidup bersih dan sehat dilakukan melalui cuci tangan pakai sabun, menggunakan air bersih untuk keperluan rumah tangga, menjaga kebersihan dan keamanan makanan, menggunakan jamban sehat, dan mengupayakan kondisi lingkungan yang sehat (Menteri Kesehatan Republik Indonesia, 2017).

\section{KESIMPULAN}

Kesimpulan dari program kemitraan kepada masyarakat bagi pendidik dan peserta didik di SD Negeri 1 dan 2 Hatu antara lain :

1. Kegiatan penyuluhan Perilaku Hidup Bersih dan Sehat (PHBS) tatanan sekolah bagi peserta didik di SD Negeri 1 Hatu, pengetahuan siswa semakin meningkat yaitu untuk nilai baik $(\geq$ $70)$ dari 42 orang $(87,5 \%$ - pretest) menjadi 45 orang $(93,7 \%$ - posttest $)$, nilai mean meningkat dari 79,6 menjadi 87,1 dan median meningkat dari 80 menjadi 90.

2. Kegiatan penyuluhan di SD Negeri 2 Hatu, pengetahuan siswa semakin meningkat yaitu untuk nilai baik $(\geq 70)$ dari 66 orang $(86,9 \%$ pretest) menjadi 71 orang $(93,5 \%$ - posttest). Sedangkan nilai mean meningkat dari 83,6 menjadi 87,5 dan median meningkat dari 85 menjadi 90.

3. Kegiatan praktek massal yang telah dilaksanakan adalah praktek cuci tangan pakai sabun, menggosok gigi dan memilah sampah sesuai jenisnya

4. Kegiatan Focus Discussion Group mendorong pimpinan sekolah dan guru untuk membiasakan PHBS serta menghasilkan buku pedoman penerapan PHBS di sekolah.

5. Pemeriksaan kecacingan menunjukan bahwa dari 12 sampel feses, ada 5 sampel yang positif telur cacing Ascaris lumbricoides

\section{UCAPAN TERIMA KASIH}

Ucapan terima kasih penulis sampaikan kepada Direktorat Riset dan Pengabdian Kepada Masyarakat yang telah memberikan bantuan pendanaan kepada penulis melalui skema pendanaan Program Kemitraan Masyarakat (PKM) tahun 2018. 


\section{DAFTAR PUSTAKA}

Banun, T. S. (2016). Hubungan Antara Pengetahuan PHBS dengan Pola Hidup Sehat Siswa di SD Tamanan. Jurnal Pendidikan Guru Sekolah Dasar, 14(9), 378-386.

Bina Kesehatan Anak. (2015). Pedoman Akselerasi Pembinaan dan Pelaksana UKS.

Bisara, D., \& Mardiana. (2014). Kasus Kecacingan pada Murid Sekolah Dasar di Kecamatan Mentewe, Kabupaten Tanah Bumbu Kalimantan Selatan Tahun 2010. Jurnal Ekologi Kesehatan, 13(3), 255-264.

Chadijah, S., Sumolang, P. P. F., \& Veridiana, N. N. (2014). Hubungan Pengetahuan, Perilaku, dan Sanitasi Lingkungan dengan Angka Kecacingan pada Anak Sekolah Dasar di Kota Palu. Media Litbangkes, 24(1), 50-56.

Diana, F. M., Susanti, F., \& Irfan, A. (2014). Pelaksanaan Program Perilaku Hidup Bersih dan Sehat (PHBS) di SD Negeri 001 Tanjung Balai Karimun. Jurnal Kesehatan Masyarakat, 8(1), 46-51.

Kementerian Kesehatan RI. (2011). PHBS di Sekolah.

Koem, Z. A. R., Barens, J., \& Sondakh, R. C. (2015). Hubungan Antara Pengetahuan dan Sikap dengan Perilaku Hidup Bersih dan Sehat (PHBS) pada Pelajar di SD Inpres Sukur Kecamatan Airmadidi Kabupaten Minahasa Utara. Jurnal Ilmiah Farmasi, 4(4), 290-294.

Menteri Kesehatan Republik Indonesia. Penanggulangan Cacingan (2017).

Noverawati, R., Setiawan, R., \& Indarna, A. A. (2012). Gambaran Pelaksanaan Siswa Tentang Perilaku Hidup Bersih dan Sehat (PHBS) Tatanan Sekolah di SDN Hegarmanah 1 Desa Hergarmanah Kecamatan Jatinangor Kabupaten Sumedang. Bhakti Kencana Medika, 2(4).

Nuryani, D. D., \& Yustitia, I. (2017). Hubungan Personal Hygiene dengan Penyakit Kecacingan pada Anak Sekolah Dasar di Dusun Pangkul Tengah Desa Mulang Mayang Kecamatan Kotabumi Selatan Kabupaten Lampung Utara. Jurnal Dunia Kesmas, 6(2), 97-103.

Rahmadhini, N. S., \& Mutiara, H. (2015). Pemeriksaan Kuku sebagai Pemeriksaan Alternatif dalam Mendiagnosis Kecacingan. Majority, 4(9), 113-117.

Sari, N. I., Widjanarko, B., \& Kusumawati, A. (2016). Faktor Faktor yang Berhubungan dengan Perilaku Hidup Bersih dan Sehat Sebagai Upaya Untuk Pencegahan Penyakit Diare pada Siswa di SD N Karangtowo Kecamatan Karangtengah Kabupaten Demak. Jurnal Kesehatan Masyarakat, 4(3), 1051-1058.

Sulastri, K., Purna, I. N., \& Suyasa, I. N. (2014). Hubungan tingkat pengetahuan dengan perilaku anak sekolah tentang hidup bersih dan sehat di sekolah dasar negeri wilayah puskesmas selemadeg timur ii. Jurnal Kesehatan Lingkungan, 4(10), 99-106. 